Volume 1

Number 2 Secrecy and Authoritarianism

February 2018

\title{
Trivialized Content, Elevated From: Aesthetics of Secrecy in Turkish Politics in the 2000s
}

Doruk Tatar

University at Buffalo, SUNY, doruktat@buffalo.edu

Follow this and additional works at: https://scholarworks.sjsu.edu/secrecyandsociety

Part of the International and Area Studies Commons, International and Intercultural Communication Commons, Political Science Commons, and the Sociology Commons

\section{Recommended Citation}

Tatar, Doruk. 2018. "Trivialized Content, Elevated From: Aesthetics of Secrecy in Turkish Politics in the 2000s." Secrecy and Society 1(2). https://doi.org/10.31979/

2377-6188.2018.010204 https://scholarworks.sjsu.edu/secrecyandsociety/vol1/iss2/4

This Article is brought to you for free and open access by the School of Information at SJSU ScholarWorks. It has been accepted for inclusion in Secrecy and Society by an authorized administrator of SJSU ScholarWorks. For more information, please contact scholarworks@sjsu.edu. 


\title{
Trivialized Content, Elevated From: Aesthetics of Secrecy in Turkish Politics in the 2000s
}

\begin{abstract}
This essay will first provide a brief history of the Islamist party's coming to power by means of its effective use of a populist imagery. The paper will then focus on the emergence of a new regime of secrecy in Turkish politics by looking at two high-profile legal cases, Ergenekon and the "Cosmic Room," in which one can observe the blueprints of a struggle between different factions for taking over the state. During the investigations, secret documents about the wrongdoings of the secular establishment were leaked to and widely covered by the media. Sober debates on the contents of such documents were dwarfed by the tendency to scandalize, stigmatize, and foster fascination for the purported clandestine organizations within the state in line with conspiracist aesthetics. In later sections of the paper, the elements of entertainment and seriousness of this conspiracist aesthetics are analyzed.
\end{abstract}

\section{Keywords}

aesthetics, conspiracism, Recep Tayyip Erdoğan, secrecy, Turkey

This article is available in Secrecy and Society: https://scholarworks.sjsu.edu/secrecyandsociety/vol1/ 


\title{
Trivialized Content, Elevated Form: Aesthetics of Secrecy in Turkish Politics in the AKP Era
}

\begin{abstract}
This essay will first provide a brief history of the Islamist party's coming to power by means of its effective use of a populist imagery. The paper will then focus on the emergence of a new regime of secrecy in Turkish politics by looking at two high-profile legal cases, Ergenekon and the "Cosmic Room," in which one can observe the blueprints of a struggle between different factions for taking over the state. During the investigations, secret documents about the wrongdoings of the secular establishment were leaked to and widely covered by the media. Sober debates on the contents of such documents were dwarfed by the tendency to scandalize, stigmatize, and foster fascination for the purported clandestine organizations within the state in line with conspiracist aesthetics. In later sections of the paper, the elements of entertainment and seriousness of this conspiracist aesthetics are analyzed.
\end{abstract}

Keywords: aesthetics, conspiracism, Recep Tayyip Erdoğan, secrecy, Turkey

Secrets are not solely made of hidden, unknown content. Form is just as important in understanding secrets and secrecy. In particular, secrecy is largely determined by how the secret is articulated, perceived, and imagined in a given political narrative and its aesthetic regime. In Edgar Allan Poe's The Purloined Letter (1884), for instance, the content of the mysterious letter is never revealed but a whole set of relations and positions - in other words, the plot itself - is woven around it. Umberto Eco's Foucault's Pendulum (1988) is about how belief in a non-existent secret bears murderous consequences. In both texts secrets move the plot without their content being revealed at all. Though it is not a work of fiction, the dominant political rhetoric in Turkish politics in the last decade 
reveal a series of cases in which the content of secrets was saliently trivialized whereas the politico-aesthetic aura that surrounded these secrets became more and more influential in perceiving, imagining, and talking/writing about politics. Revelation, no matter how solid and unquestionable the proofs are, has therefore lost its purchase on the collective consciousness in Turkey. In that regard, a phenomenon similar to "post-truth" has been in effect in Turkish politics almost for a decade.

This paper will present a theoretical framework for political secrecy from the perspective of aesthetics, which signals a type of relation whose main axis is not that of knowing and not-knowing but instead emphasizes affective investments, lines of identification, and what Sigmund Freud has termed "qualities of feeling." This article does not aim at conducting a sociological analysis of political secrecy. Aesthetics will instead allow us to discuss the subject with respect to nonempirical data.

I use the term aesthetics with Immanuel Kant's ideas in Critique of the Power of Judgment in mind. According to Kant (2000), aesthetics is not bound up with qualities innate to objects, that is to say, whether they are inherently or essentially good, bad, beautiful, and ugly. It hinges on the subjective judgment of qualities of objects. Yet, Kant maintains that aesthetics, despite its subjective nature, needs to be communicable to others. In that regard, Kant's formulation of aesthetics makes way for our theory about secrecy that is not primarily about secret content but the domain of subjective judgment and the social imagination woven around it. 
Sigmund Freud's ideas on paranoia will also inform the theoretical discussion in this article insofar as his method of analysis is closely related to the realm of aesthetics, which for him is not merely "the theory of beauty," but also "the theory of the qualities of feeling." In his essay, "On the Mechanism of Paranoia," Freud ([1911] 1997) points to the significance of the psychical processes of fixation, displacement, identification, and projection in paranoia. He, moreover, presents an ambivalent affective structure as in the case of the juxtaposition of love, hate, and aggression. This ambivalence is the dominant structure that marks the state of paranoia in which "delusions of persecution" are accompanied by libidinal investments. Accordingly, Freud's understanding of paranoia makes way for an emphasis on the aesthetic form of the secret over its content. He describes it as a psychic state determined by libidinal investments along the axis of love and aggression rather than formulating it through positions of knowledge and ignorance.

In this article, I will first present a brief account of the rise of Recep Tayyip Erdoğan's party to power, and then dwell on the populist discourse and the historical/ideological reasons that made this ascension possible. ${ }^{1}$ This background is crucial for understanding the role of conspiracy narratives as effective and pleasurable "cognitive mappings," as Fredric Jameson (1990) has termed it, within the prevalent political culture in Turkey. I then focus on two important two conspiracy cases namely, namely Ergenekon and the "Cosmic Room," which not only signaled the heightened power struggle within the state but also indicated the changing regime of secrecy and its aesthetics. Both cases will be analyzed 
Secrecy and Society, Vol. 1, No. 2 [2018], Art. 4

with reference to their dominant narratives and aesthetic features that helped citizens to understand political events, to take positions, and to form identifications with various "faces of the state" (Navaro-Yashin, 2002).

\section{The Struggle for Hegemony between the "Center" and the "Periphery"}

There have been two events in particular that showcase the recent shift in Turkish politics. The first are the tape scandals of 2014 , in which leaks of telephone conversations between several high-profile businessmen and politicians including Recep Tayyip Erdoğan, who was the Prime Minister of Turkey at the time, and his son, Bilal Erdoğan (which were illegally tapped and recorded) were revealed to the public through a website on an almost daily basis. Despite the serious and incriminating contents of those conversations, the government did not suffer a loss in its popular support as reflected in its electoral mandate. This case exemplifies the trivialization of secret content against a background in which the power of revelation displays autonomy from that which is revealed.

The second example is Erdoğan's presidential campaign advertisement in 2014. The ad starts by showing people "from all walks of life" who take over the stars of the presidential pennant from older people dwelling in different parts of Asia Minor. The new custodians start off by car, boat, and bullet train (one of the major investments the government has taken pride in), on horses (a tribute to a Turkic past and traditions), and bring the stars to the gates of the presidential palace. Then they place the stars on a panel on the gate at which point Erdoğan shows up to place the largest star in the center. Once all stars are present on the 
panel, the gates open, and Erdoğan walks in followed by the people. ${ }^{2}$ The message is clear: the people gain access to the state, which had been previously closed to them, through Erdoğan's election as the new president. In Erdoğan's own terms, his election will bring about the dawn of a "New Turkey," in which the state and the people (nation) convene, unlike in previous stages of modern Turkey. The trivialization of secret content in the first example can be explained with respect to the prioritization of the imaginations of unity between the state and the people in the latter example.

Erdoğan and his Islamist party, the Justice and Development Party (AKP), have based their populist rhetoric on deeply rooted ideological and cultural faultlines that go back to the early stages of the modern Republic (1920s and 30s) and the late Ottoman period (19th century). To understand these fault-lines in the politics and social fabric of Turkey, we have to look at the ideas of a prominent Turkish sociologist, Şerif Mardin. According to Mardin (1973, 169), the Ottoman Empire "emerges as an outstanding exception" to the Middle East, due to its "lasting center supported by a sophisticated network of institutions." Mardin frames Turkish politics as having been defined by the relations of assimilation, friction, and incorporation between the "center" and the "periphery." For Mardin, the classical Ottoman political structure consisted of two poles, namely the political center represented by the Sultan and his bureaucrats on the one hand, and the periphery represented by a highly heterogeneous Ottoman Anatolia (Asia Minor) on the other. During the comprehensive modernization project, which was initiated and carried out by the central state in the 19th century, new dimensions 
Secrecy and Society, Vol. 1, No. 2 [2018], Art. 4

were added to this separation as traditional power-holders in provincial areas took a reactionary position by formulating a peripheral identity laden with traditional and religious motifs against the modernizing and secular thrust of the center. Mardin suggests that this fault-line persisted after the demise of the Ottoman Empire and the foundation of the modern republic. The attempts of the periphery to move to the center, however, were repeatedly suppressed by the central political establishment (military-bureaucracy) through absolutist interventions into politics such as recurrent military coup d'états ${ }^{3}$ (Mardin 1973). Mardin's theory is important as it has been widely alluded to by pro-AKP scholars and intellectuals, and the spatial imagery of the center-periphery dichotomy has delineated the AKP's success in re-establishing the ties between the state and the people.

At this juncture, we can turn to Cihan Tuğal's ethnographic research into the AKP's rise to power, which he describes as a social response to a longstanding "organic crisis." The concept of an "organic crisis," which Tuğal (2009, 24) borrows from Antonio Gramsci, stands for "a broad overlap and mutual reinforcement along several axes, including both the factors that modernization and social movement theories have pointed out but also class-related and spatial crises" that undermine the conditions of possibility for the social integration. Tuğal $(2009,42)$ examines how the Islamist-politics responded to this "organic crisis" along the "axes of hegemony with reference to political leadership, authority structures, imaginations of unity, everyday life, transforming the social space, and economy relations." In this essay, the first three categories, namely 
political leadership, authority structures, and imaginations of unity, will be examined in order to draw the contours of a political fantasy that determine the framing of political secrecy in the Turkish context in which the state occupies a central position in the processes of collective imaginations and identifications.

Tuğal describes the severed unity of the state and the political community as one level of "organic crisis." Against this backdrop, the survival of the reigning hegemonic project is contingent upon its ability to realize the promise of unity. With the failure of this promise, the hegemonic project became vulnerable to onslaughts coming from both inside and outside the state $(2009,241)$. In Tuğal's view, the Islamists were successful in re-instituting the unity between the state and the political community, and thus became capable of overcoming the organic crisis that had been in effect throughout the 1980 s and 1990s. They pacified and assimilated the radical features of their ideological orientation in a process that Tuğal describes as a "passive revolution."

To translate this process roughly into the terms of Mardin's theory, the organic crisis can be seen as the result of a failure in governing and managing the center-periphery relations, which then helped a peripheral political actor to move to the center. Here, it should be noted that the Turkish state is the central actor in manufacturing consent; an ability that the state largely lost in the 1980 s and 1990s, during which time established political figures were held responsible for the persistent problems of the country such as corruption and shortsightedness. This situation led to a desire for savior figures. On that note, Tuğal $(2009,94)$ describes "political society [as] this interlocking of political leadership with 
Secrecy and Society, Vol. 1, No. 2 [2018], Art. 4

authority figures - only their interaction and joint activity can link citizens to the state." Based upon this observation, it is easy to see how Erdoğan, the incumbent president of Turkey, fulfilled that societal expectation in the years following the AKP's coming to power.

The military had been the main constituent of the old establishment and its institutionalized involvement in Turkish politics posed the most serious challenge to the AKP's "passive revolution." In 1997 it was the military that ousted another Islamist party from the government through a "postmodern" military coup, a coup without coup. As has often been asserted, the AKP was the direct result of this event. ${ }^{4}$ Tuğal $(2009,120)$ writes:

The military intervention of 1997, which repressed Islamic organizations and parties nationwide, also decreased their activities in this particular district and closed down some of their sites of agitation, such as religious teahouses and youth organization centers. Especially important was the shutting down of the teahouse adjacent to the central mosque, which was the main organizing ground of Islamic communities. This military unlinking of Islamic political and civil society, however, had no positive counterpart, that is, the relinking of civil society and secularist state. This incapacity contributed to the persistent organic crisis in Turkey.

Tuğal suggests that the failure of the military intervention in replacing the existing social relations under Islamist influence with new ones exacerbated the organic crisis between the state and various social segments. This provided the AKP with a more fertile ground to flourish and a stronger hand in its confrontation with the military. Relying on its strong electoral mandate in the aftermath of the general elections in 2007, the AKP plunged into the project of "civilianizing" Turkish politics and diminishing the military's influence in politics "by implementing legal reforms that reduced the institutional power of the military in 
decision making," and "through the political de-legitimisation of the military's extra-legal interventions in politics" (Esen and Gümüsçü 2016, 1584). In line with the second principle, the AKP went a step further and criminalized the army's involvement in politics through trials such as the Ergenekon ${ }^{5}$ and Sledgehammer [Balyoz] cases, where numerous retired and active high-ranking soldiers were tried and forced to respond to the accusations of plotting to illegally overthrow the elected government (Esen and Gümüsçü 2016, 1584-85). ${ }^{6}$

The Ergenekon trial was the first case that shook existing military-civilian relations in Turkish politics as the above-mentioned aspects of civilianization came to the forefront throughout the trial and the debates around the affair. The case started in 2007 and it was officially closed in 2016. It is worth quoting a short summary of how the Ergenekon case began:

On June 12, 2007, acting on an anonymous tip-off, the Turkish police discovered a crate of grenades in a shantytown in the Istanbul suburb of Umraniye in the beginning of what later became known as the Ergenekon investigation. By May 2011, a motley collection of over 300 people had been formally charged with membership of what public prosecutors described as the "Ergenekon terrorist organization," which was allegedly plotting to use violence to try to destabilize the government of the moderate Islamist Justice and Development Party [AKP]. In January 2010, prosecutors launched a parallel investigation into claims that members of the Turkish military had plotted to stage a coup against the [AKP] in early 2003. By May 2011, 195 serving and retired members of the Turkish military had been formally charged with involvement in the alleged plot. (Jenkins 2011, 1)

Even though the case was received with hope and enthusiasm at first, a number of irregularities came to light in the subsequent stages of the trial. Gareth Jenkins $(2009,13)$, for example, describes the later stages of the affair as a transition from "plausible paranoia" to "the politics of the absurd." 7 In a similar 
Secrecy and Society, Vol. 1, No. 2 [2018], Art. 4

vein, the Secularist-Kemalist camp that assumed a critical stance toward the trial, pointed out inconsistencies and legal miscarriages to demonstrate the political aspiration of the Islamist government to take over the state and silence critical and oppositional voices. The opposite camp that was composed of Islamists and liberals, on the other hand, celebrated the investigation as a rare opportunity to democratize political culture and normalize the civilian-military relations by eliminating "gang-like entities" within the state. Beside its positive aspects, the latter camp argued, the case also revealed the existence of a serious threat to Turkish democracy in the form of coup plans against the democratically elected AKP government as well as numerous political assassinations that were planned to create chaos (Balcı 2010).

\section{The State Meets the People: "New Turkey" as a Political Fantasy}

Those who were convinced by the allegations of the Ergenekon trial took the whole affair very seriously because it was believed that the civilian and democratic base for politics could be destroyed by military intervention. However, the attitude of taking it seriously was not purely about the magnitude and proximity of the danger. There was also a performative dimension to this seriousness that is always-already mediated by a regime of aesthetics that we can call "conspiracist."

Conspiracism is a dominant political rhetoric in Turkey but it is not merely a reaction to the inaccessible and secretive modus operandi of the state, as in the case of Western liberal regimes - at least in the pre-Trump period - where 
conspiracy theories are articulated as popular and populist responses to a democratic deficit and a lack or shortage of state transparency (Bratich 2008). In the context of the Middle East, conspiracy narratives do not function as popular sense-making devices that are excluded from the political center. On the contrary, as Matthew Gray (2010) points out, conspiracism is an integral part of the official political rhetoric in Middle Eastern countries since it is a crucial tool employed by states with the aim of and manufacturing consent by grasping the masses' imagination and having them identify with states/sovereigns. In that respect, it would not be far-fetched to suggest that conspiracism brings its own aesthetic surplus that exceeds the content of secrets while entertaining narratives and scenarios are publicly circulated, exchanged, consumed, and enjoyed.

The Ergenekon case was aesthetized with reference to the organization's ties to international politics. As has been argued, the origins of the organization goes back to the foundation of the North Atlantic Treaty Organization (NATO), whose driving principle was the containment of Communism through various legal and extra-legal means, including what is commonly known as the Gladio program. These clandestine stay-behind anti-Communist networks ingrained into nation-states, especially those that seemed to be under imminent danger of Communist influence in Europe, namely Italy, Greece, and Turkey (Taş 2014). ${ }^{8}$ Here, we see the hints of an ongoing conspiracy with international connections while the initial focus was on the organization of Ergenekon as an internal enemy, a fifth-column, and even parasite-like entity - as imagined in organicist views - 
Secrecy and Society, Vol. 1, No. 2 [2018], Art. 4

undermining the inevitable progress of Turkey and the actualization of a "New Turkey."

The top politicians of that time did not abstain from commenting on the Ergenekon case, including two cabinet ministers, Bülent Arınç and Egemen Bağış: "Turkey is cleaning its intestines," "We have seen that those who were used to hunt in muddy waters in Turkey have tried to put obstacles in front of us [the government]. ${ }^{\prime \prime}$ Arınç's statement resonates with Julia Kristeva's $(1982,2)$ concept of "abjection," that which is cast off from one's identity. That said, the clandestine organization of Ergenekon is thus "within" the state, but not native to it. On the contrary, it is utterly foreign, essentially detachable, and in fact should be cast off in order for the state's body(-politic) to return to its natural state. Bağış's statement demonstrates a recurrent theme of the AKP's and especially Erdoğan's political discourse that claims the existence of certain forces shackling Turkey's progress, which has to do with the notion of unity (between the state and the political community) as a way out of the "organic crisis." 10

These examples of official rhetoric revolving around the Ergenekon case signify the surplus element of fantasy that is a pivotal element of conspiracy narratives. According to Slavoj Žižek (1995), fantasy is the surplus element that keeps the symbolic order operative in the face of internal limits and inconsistencies. For Žižek (1995), one way in which fantasy functions is through the projection of an internal limit onto an external obstacle, whose presence is the only hindrance to the actualization of a perfect balance and harmony. This sheds a new light on the discussion of the "organic crisis" that was overcome by 
the AKP. The Islamist project has long imagined itself to be the natural representative of the nation, the silent and oppressed masses. As they obtain more power and influence, the project of bringing the state and the people (or nation) together has become more salient. Consequently, what is associated with Ergenekon - "gangs nested within the state" [devlet içinde yuvalanmış çeteler] as pro-government media described it - works as not only a scapegoat that can be blamed for all shameful moments in Turkish history (including coup d'etats, political assassinations, even the Armenian genocide in 1915). It is, however, also a fantasy element that prevents the organic convergence between the state and the nation, the center and the periphery.

Exposing the links between an internal enemy and foreign forces, the scope of an originally national conspiracy expands to an international level. ${ }^{11}$ The expansion of conspiracy narratives from a national to global level resonates with Mark Fenster's (2008) argument that the conspiracy theory always desires more secret plots to reveal, and it constantly postpones the final moment of revelation. He notes, "the more that the conspiracy has been able to consolidate power and hide its existence, and the more it threatens those who attempt to discern it, the more difficult it is for the conspiracy text to contain the narrative's conflicts and resolve its complex plot" (140). According to Fenster, fictional series such as The $X$-Files fulfills conspiracism's structure of desire by offering open-ended narratives as the expectation of ultimate revelation is postponed to an indefinite future.

In putatively nonfictional conspiracy narratives, the very act of narrating, of bringing theoretical coherence to discrete events, is itself an act of closure in its attempt to resolve the question of power. Put another way, the 
Secrecy and Society, Vol. 1, No. 2 [2018], Art. 4

conspiracy provides closure in its control over the social and political order. (Fenster 2008, 140)

Similarly, the political aesthetic of the Ergenekon case was taken to another level as the tug-of-war within the state went on. One of the sequels to the trial was the "Cosmic Room" [Kozmik Oda] incident. In December 2009, an investigation was launched after claims that two military officers attempted to assassinate Bülent Arınç then Deputy Prime Minister. The prosecutors in charge of the investigation required access to the so-called Cosmic Room, a catchy name for a storage facility containing the Turkish military's Special Ops' highly confidential documents. The guarding unit of the confidential archives initially turned down the request by referring to a legal code that mandates a special authorization for access to the room. After a daylong standoff, the military agreed to allow a civil judge to enter and take notes on the documents relevant to the case at hand (Aydınlı 2011, 234-35). Various newspapers covered this event dayin and day-out, sharing every juicy detail with the public. ${ }^{12}$

The narrative behind the coverage of the incident can be understood in the context of our earlier discussion: finally a "civilian" (an outsider to the "inner state") can enter the "Cosmic Room," the old establishment's "bedroom" where its most serious secrets are kept. It is also possible to re-imagine this affair through the spatial imagery of a center-periphery duality: the gravitational center of the state where its innermost secrets are now exposed to the eyes of an outsider (albeit one that is a high-ranking member of the judiciary). 
One of the interesting headlines about the "Cosmic Room" incident appeared in a Gülenist newspaper, Zaman: "Turkey's black-box is being opened. ${ }^{13}$ The affair can be read as a part of the process of the Islamists' ascension to the political center, and their increasing access to the "inner state" of Turkey. The inside nature of the political establishment is further emphasized by terms such as the "Cosmic Room" and "black-box," which imply spaces where the darkest and dirtiest secrets are assumed to be kept. The stakes were set as high as possible because the investigation was imagined to be a turning point for Turkey's democratization process. On the one hand, the investigation was supported by allusions to democracy, transparency, accountability, and the rule of law. On the other hand, it is possible to detect some sense of fascination accompanying civilian intrusion into the military as the kernel of the Turkish state.

Like Ergenekon's alleged ties with Cold War politics, the term "Cosmic" is borrowed from NATO terminology, where it refers to TOP SECRET information and dossiers (North Atlantic Treaty Organization 2013). With the transplantation of the term, "Cosmic Room," the affair taps into a conspiracist vision of international politics and its aesthetic arsenal while obtaining a sense of grandeur exceeding the national plane. It is as if the room opens up a realm that exceeds earthly knowledge and reaches to a level of transcendence. Burhan Kuzu, an AKP PM and then the chair of constitutional committee, for instance commented on the "Cosmic Room" affair: "There is an invisible Turkey in the background. We don't know how far its arms and branches reach. ${ }^{14}$ Through statements such as 
Secrecy and Society, Vol. 1, No. 2 [2018], Art. 4

Kuzu's, we see that this affair that apparently belonged to the plane of everyday politics and power struggle was elevated to the level of the political sublime. ${ }^{15}$ Furthermore, the "Cosmic Room" incident shows that the aesthetic features of conspiracy narratives that were already popular in the West were imported to the Turkish context. This implies a raising of the stakes in the sense that Turkish politics is imagined to be at the center of world politics due to the thriller-like coverage of the affair.

In The Origins of Totalitarianism, Hannah Arendt (1968) takes on Benjamin Disraeli, one of the most influential British Prime Ministers in the 19th century, and his view of international politics in terms of secret societies and vast conspiracies. Arendt $(1968,72)$ suggests that this way of understanding and presenting politics turned Disraeli into someone "who transformed boring transactions into dreams with oriental flavor."

A similar argument can be made regarding the widespread coverage and popularization of the "Cosmic Room" incident that became a political intrigue. It was a source of fascination, enjoyment, and entertainment given that it was presented as a turning point in history, a rupture in the monotony of politics-asusual. On the one hand, the "Cosmic Room" evoked the expansion of the world since what was in question was the existence of a whole new realm that had been unknown and inaccessible before - not so much different from what the work of fiction achieves. Moreover, the "Cosmic Room" event functioned as a chapter in the AKP's political pathos as it was presented as a step toward the actualization of the "natural" order of politics through the convergence of the people (nation) and 
the state, which can be thought of as another way of saying that the "organic crisis" was overcome and the center-periphery separation was finally abolished.

\section{The Aesthetics of Seriousness and the Play-Element}

An analysis of the subject of political secrecy through the lens of the aesthetic unearths a curious relation between two seemingly antithetic elements, namely entertainment and seriousness, both of which are present in the arguments of various important political thinkers such as Thomas Hobbes and Carl Schmitt. To begin with the former, one can suggest that Tuğal's observation on the societal yearning for savior figures that would put an end to the ongoing "organic crisis" can be elaborated with reference to Hobbes's political theory. Hobbes ([1651] 1998) imagines a hypothetical pre-political community, which is commonly known as the "state of nature," where life is "nasty, brutish, and short" due to the fact that everyone is at war with everyone else. The way out from this nightmarishly insecure state, for Hobbes, is making a contract through which everyone resigns all natural rights - to use everything and everyone else without limits - and powers to the sovereign (the Leviathan). In a Hobbesian universe, the sovereign draws its allegedly unbound rights and powers from the accumulation of its subjects' rights and powers in order to constitute and maintain a political community. That is to say, Hobbes formulates one of the main routes of escape in modern politics from an "organic crisis" qua the risk of regressing back to a nightmarish scenario in which the state is dismantled and individuals are deprived of security and certainty. 
Secrecy and Society, Vol. 1, No. 2 [2018], Art. 4

The Hobbesian contract rests heavily on human faculties like language, imagination, and fiction. Despite Hobbes's outright condemnation of literary and linguistic mediations such as metaphor, which he considers a corrosive factor in the otherwise smooth operation of the political and the sovereign, language and narrative are undeniably constitutive of the contract. In the context of early modernity, as Victoria Kahn (2004) notes, political subjects "came to think of politics as a realm of poetics, even fabrication. The fiction of the political contract was the single most important example of this way of thinking about politics" (Kahn 2004, 16). As the very idea of a contract is the product of imagination, its durability is contingent upon the subjects' habitual performance of it insofar as the contract is never fully actualized in an objective sense. This performative aspect of the contract opens up the terrain of sovereignty and politics of the question aesthetics.

What is missing in Hobbes' theory of the sovereign are the inter-sovereign relations, international politics if you will. For that we need to turn to another important thinker of sovereignty, Carl Schmitt and his conceptualization of the political. Schmitt's concept of the political owes a great deal to the Hobbesian state of nature, in which every person assumes the existence of an imminent threat from every other. For Schmitt, at the heart of the political lies the friendenemy distinction made by the sovereign/state in the "state of exception" [Ernstfall].

Schmitt $(2007,19)$ builds his theory upon a series of presuppositions; the state presupposes the political, and the political presupposes/anticipates war. 
Here, the faculty of presupposition/anticipation is constitutive of the political while it is characteristically charged with hostility and aggression. Anticipation in not only Schmitt but also Hobbes gives way to the logic of preemption as the other is construed as an "innately" dangerous agent. The innate danger of the other is caused by the other's opaqueness. In other words, what the other intends or wills is motivated by a subjective inwardness that resists outside observation and other forms of detection. This kernel of secrecy located within the other is a main source of enmity in the Hobbesian state of nature and the Schmittian understanding of the political.

The authenticity of the political in the Schmittian sense derives from a lifeand-death situation. It is the enemy as the constitutive figure of Schmitt's political that presents a scene where the sovereign's real (physical) existence is under a potentially deadly threat; a threat to be taken with utmost seriousness in a "state of exception" or "state of emergency." ${ }^{16}$ But, like Hobbes, Schmitt too repudiates the important role of aesthetics in his own theory. Even though Schmitt renders the enemy, the real possibility of war, and hence the political itself as an iron law of life as is [sein], it is possible to dig out a normative agenda that Schmitt is keen to cloak. Leo Strauss, for instance, detects an aesthetic and normative value to Schmitt's serious treatment of the political. For him, Schmitt writes with anxiety about the fate of the political, especially when he tries to affirm its "seriousness." Strauss $(2007,53)$ draws attention to Schmitt's speculation about a world that is not informed by the friend-enemy distinction: "What remains is neither politics nor state, but culture, civilization, economics, 
Secrecy and Society, Vol. 1, No. 2 [2018], Art. 4

morality, law, art, entertainment, etc." Out of all the domains, Strauss (2007,

116) picks up "entertainment" and dwells on it:

Schmitt does everything to make entertainment nearly disappear in a series of man's serious pursuits; above all, the "etc." that immediately follows "entertainment" glosses over the fact that "entertainment" is really the ultimate term in the series, its finis ultimus.

Strauss's reading suggests that the concept of the political (and the state), in this context, turns into a kind of guarantee against a world of entertainment devoid of politics and seriousness. Here, we start to grasp the contours of Schmitt's aesthetics whose lynchpin is the "serious," self-assigned task to shield the seriousness of the political against the trivializing influence of entertainment.

Strauss $(2007,117)$ thinks that Schmitt affirms the political as the proper expression of the "seriousness of human life," which is "ultimately nothing other than the affirmation of the moral." This possibility of real/physical death is what gives life its meaning, its seriousness, and eventually its beauty.

Seriousness, then, can be conceptualized as a "structure of feeling," to borrow from Raymond Williams's term, which is inseparable from Schmitt's concept of the political and the figure of the enemy. In Schmitt, the enemy brings with himself the possibility of war and hence death for one of the warring parties. And the possibility of war lays the ground for a "politics of authenticity" with its own notions of heroism and glory as it elevates life from the plane of the trivial, the mediocre, and the ordinary. Schmitt's promotion of the exception over the norm translates into "the temporal semantics of discontinuity," and hence exception (Wolin 1992, 433). Accordingly, Schmitt invests also aesthetically into 
the state of exception. However, we can additionally argue that the state of exception fosters an aesthetic reaction on the part of the viewers, who are fascinated by the idea of bearing witness to an exceptional situation as in the case of the "Cosmic Room" incident, which was imagined as a historical moment where the "black-box" of the state was being opened and glimpsed at. This is also the moment that Jenkins (2009) points out in relation to the Ergenekon case when it moved from "plausible paranoia" to "the politics of the absurd" where legal anomalies were to be ignored.

This quick transition from "plausible paranoia," which implies a "serious" situation due to the authenticity of the threat, to "the politics of the absurd," where seriousness is replaced by playfulness, levity, entertainment, etc., overlaps with the ambiguous relation between seriousness and play in Schmitt. Johan Huizinga is one of the scholars who criticized Schmitt's exclusion of play-element from the realm of seriousness. According to Huizinga $(1949,1)$, "[i]n play there is something 'at play' which transcends the immediate needs of life and imparts meaning to the action." The fun aspect, for Huizinga, does not exclude seriousness but qualifies the essence of play since it implies a certain kind of "cynic" distance between one's actions and thoughts. To put it differently, those who play games are aware of the fact that they are doing something essentially irrational but they continue to do so nevertheless. Huizinga relies on the idea of the undeniability of play in his critique of Schmitt's prioritization of the political along with the serious gesture of sovereign decision. By asserting the undeniable presence of the play-element within seriousness, Huizinga challenges Schmitt's 
Secrecy and Society, Vol. 1, No. 2 [2018], Art. 4

repression of the role of aesthetics in his concept of the political. In the same vein, Carlos Galli (2012) examines this uneasy interaction between seriousness and aesthetics (of play) that is disavowed in Schmitt's essay by emphasizing Schmitt's deliberate use of the term emergency [Ernstfall] due to its evocation of seriousness [Ernst] as a response to Johan Huizinga's polemical stance toward his theory of the political. In Galli's $(2012,76)$ words:

Schmitt's "struggle for struggle's sake" is, for Huizinga, the real game, while struggle with a finality of objective domination, despite its violation of the "rules of the game," would remain within the realm of the primitive aspiration to "glory." In this way, the total war Schmitt theorized in the 1930s - despite its barbarism, which destroys the "game" of international law - would still result in something ludic, even though primitive, but in any case not serious. [...] In this type of war, the enemy is existentially and primarily inimical, and the ludic elements of politics [...] depend, as secondary, political-statual elements, on the historical happenings of the "political." For his part, of course, Schmitt, excludes the possibility of politics as a "game" completely deprived of conflict.

As Schmitt is thus concerned with a general mood of liberalism, which, for him, has a natural predisposition toward "the levity of play" and the neutralization of the negativity (the friend-enemy distinction) at the core of the political, Galli $(2012,77)$ teases out the playful aspect of the political implicit to the Realist vision of politics. In the same vein, "the temptation to read into play the destiny of politics" exists within "the tendency towards demythicization." In other words, Schmitt's vision of the serious world of the political is not naked or purely immanent to the reality-as-is but is always-already mediated by an aesthetic distance. It is open to be filled out by various supplements including the aesthetics of play and even entertainment. Against this background, we can refer to the Great Game - a term that became popular with Rudyard Kipling's 
imperialist novel Kim and designates international politics whose ultimate aim is the world domination - that consists of "the fascination with politics as undifferentiated freedom (and not as decision)" (Galli 2012, 77). What we see here is a slip from Schmitt's serious "decisionism" to the regime of playful freedom in the Great Game.

Though it was repeatedly used in conspiracist texts and discourse, the term, the Great Game became extremely popular with an AKP-sponsored documentary called the "Great Game" after the Gezi protests in 2013. ${ }^{17}$ The main argument of the documentary is that there is a hidden hand orchestrating seemingly unrelated events including the protests, and the main objective of this hidden hand is to destroy Turkey's progress under the AKP rule. Firstly, we see the juxtaposition of game and seriousness. The "Great Game" that was being played on Turkey through the Gezi protests posed a deadly serious threat to the peace and harmony between the state and the people, or more accurately the nation. Secondly, the rejection of the possibility that massive protests can take place on their own demonstrates the mindset that composed the documentary. Here, the "Great Game" functions as a cognitive map for and a way of making sense of the mass protests, which seemed to emerge "out of the blue." What many interpreted as an immensely complex social phenomenon was reduced to the logic of the friend-enemy distinction, and in line with this, the supposed danger hidden in the "inwardness" of the event was to be decoded and responded to with alertness.

Accordingly, we can read Schmitt's framework as a way of understanding the world as a cosmos populated by sovereign entities of friends and enemies. To 
Secrecy and Society, Vol. 1, No. 2 [2018], Art. 4

put it in another way, the friend-enemy distinction represents the world in its totality, and in this sense it corresponds to what Fredric Jameson calls "cognitive mapping." According to Jameson (1990), conspiracy theories are narratives that enable the subject to conceive of the world in its totality despite the fact that this perception might be skewed, awry, and simply untrue. Accordingly, conspiracy theories have a psychological function by providing explanations and alleviating the fear and anxiety caused by a world that is hard to understand, experience and navigate for subjects. Additionally, conspiracy theories, for Jameson (1990), are sense-making mechanisms that are necessary for political action. However, this essay proposes to move beyond a functionalist reading of conspiracy theories insofar as our discussion thus far has revolved around the question of aesthetics in relation to secrecy and conspiracy in the context of Turkey. Though democratic deficit and lack of transparency play significant roles in the popularization of conspiracism, one should also consider the affective and aesthetic links that are forged by conspiracy narratives between the state and its population.

\section{Coda: Cynicism in the Interstices of Knowing and Not-Knowing}

Turkish politics offers rich soil for conspiracy narratives whose main objective is not to detect and reveal facts hidden from the public eye but to forge narratives that coalesce the state and its citizens/subjects into one unity through rhetoric performances of detecting and revealing conspiratorial plots targeting them in toto, thus their unity. In her ethnographic study of the Turkish state and civil society in Turkey in the 1990s, when what Tuğal designates as the "organic 
crisis" was still in effect, Yael Navaro-Yashin (2002) examines state-sponsored conspiracies and crimes in a fashion similar to that of Freud. According to NavaroYashin $(2002,180)$, the criminal involvements of the state, which was widely covered in newspapers at that time, turned out to be a factor in people's alienation from the state. At the same time, however, conspiracy narratives on the criminal face of the state created their own "magnetic pull and push" that informed then political culture of Turkey at that time. At this juncture, NavaroYashin $(2002,182)$ criticizes the Foucauldian framework that "would focus on conspiracy as representation, face by default the danger of trivializing and normalizing a state's discourse of unity and transparency that would represent power otherwise." For her, conspiracy narratives do not only operate as discourses within a certain political culture but they also indicate bodily experience insofar as the regime of fear and enjoyment is embedded in subjects' bodies and psyches.

According to Navaro-Yashin, the widespread corruption of and conspiratorial relations within the Turkish state engendered oblivion and cynicism among citizens. And it is only through cynicism, Navaro-Yashin $(2002,179)$ asserts, that the "everyday life of statecraft" remained operative as citizens could continue to identify, albeit cynically, with the state. Yet, it is necessary to clarify some points regarding the concept of cynicism. Cynicism implies an emotional and affective distance between the cynic and of the object of his cynicism. It is therefore not altogether wrong to assume the existence of such cynic distance, and we should also note that this distance is far from stable as in the case of the "magnetic pull 
Secrecy and Society, Vol. 1, No. 2 [2018], Art. 4

and push" - in the form of fascination and repulsion - of the state's crimes on its subjects. Furthermore, the discussion of cynicism in Turkey in the 1990 s can easily lead us to a hasty conclusion that cynicism was replaced by a devout and "serious" - lacking cynic distance - identification with the state once the "organic crisis" was overcome by the AKP's social, political, and economic success in the early 2000s.

The final blow to the military's long shadow over Turkish politics came about with the constitutional referendum in 2010. The military's influence in politics was reduced to a minimum, if not eliminated altogether, with the constitutional amendments. Meanwhile, the power vacuum was filled by Islamist factions, and one particular Islamist group came into prominence, namely the Gülenists - the name derives from a Turkish cleric called Fethullah Gülen. Once the military was out of the way, the alliance between the Islamist government and the Gülenists did not last long. Just three years after the referendum, in December 2013 a criminal investigation was launched targeting several key figures in and close to the Turkish government including family members of some cabinet ministers. Despite the presentation of the investigation as an anticorruption initiative, it was more widely conceived of as the power struggle between Gülenists and the government coming out in the open. Following this event, before the local elections in 2014, recordings of phone conversations including one between then Prime Minister Erdoğan and his son were leaked on the Internet (Letsch 2014). Erdoğan responded to the leaked tapes by branding them as "immorally fabricated" and a conspiracy orchestrated by the US-based 
cleric Fethullah Gülen "to discredit his government before local elections" (Associated Press 2014). What is even more interesting was that the event dominated the newsfeeds for weeks but had virtually no impact on the electoral support for Erdoğan and his party.

The whole affair can be viewed as a symptomatic example of the dominant regime of secrecy. The failure of those who leaked the tapes - probably with the expectation of making a dent in Erdoğan's and his government's dominion over Turkish politics - were at fault due to their unshaken belief in the revelation of scandalous and incriminating content. Yet, as discussed in this essay, secrets are not merely composed of their contents. Herein, Erdoğan succeeded in turning this incident into another thrilling and entertaining narrative of a vast and sinister conspiracy taking place against himself and his government. Furthermore, the belief in the power of what is revealed is based on the assumption that there is an epistemological gap between those who know and those who do not. In that respect, one can argue that those who leaked the tapes probably assumed that people would change their view of Erdoğan and his government after they learned of the backstage reality. Yet, it might very well be the case that those who are assumed to be ignorant of a secret are in fact as informed as those who imagine themselves to be the exclusive owners of that secret.

At this point, we can recall the notion of cynicism, which had been in the foreground in Navaro-Yashin's depiction of citizen-state relations in the 1990s, and claim that cynicism in this case consolidates the organic unity, as it can be observed in the AKP sympathizers' remarks defending their party: "They steal but 
also serve/work" [yiyorlar ama çalışıyorlar] and "who does not steal" [kim çalmıyor ki]. Going back to Žižek's framework of fantasy and the structure of perversion, we see that people already knew - or at least sensed - what the recordings revealed. It should be emphasized that in the Ergenekon case, the unearthing of political secrets had a serious impact. This was not due to what the revealed contents signified but because of the weakened ties of identification (a layer of the "organic crisis") between the old establishment (militarybureaucracy) and the people. However, the social, political, and ideological ties between the AKP/Erdoğan and large segments of society were still strong when the tape leaks started. That is to say, due to people's identification with Erdoğan, the leaked tapes did not have the same kind of energizing (support for the government) and alienating (turning away from the military) effect as in the case of the Ergenekon and "Cosmic Room" affairs. It would not be far-fetched to claim that the mere impact of the phone-tapping scandal derived not from the secret contents they revealed but from the fact that they could tap the most private conversations of powerful figures, including the mightiest one, Erdoğan himself, which was a show of strength, regardless of the contents of the recordings.

In the last two decades or so, scholars have omened the coming of a new paradigm, which can be coined as post-Enlightenment. With regard to the subject of transparency and secrecy, Jean and John Comaroff (2003) provide one such example where they interpret the rise of conspiracism in the 1990s as a sign of the arrival of an epistemology of suspicion that challenges the politics of Enlightenment where seeing and knowing overlap. During the latest wave of 
right-wing populism across the world, and especially in the aftermath of Donald Trump's election as the president of the USA, the same theme came to the forefront, more forcefully this time and expressed by another term, "post-truth." What we see in the case of Trump, which would have been unimaginable in the previous paradigm, is his near invulnerability to various kinds of revelations including incriminating connections, conflict of interest, inconsistencies in rhetoric and policies, and even sexual harassment. It is as if that which was revealed about Trump failed to overrun the mechanisms of identification and making it relevant to the subjects' attention. The supremacy of form - composed of identification, affective investment, aesthetic pleasure, etc. - over the content of secrets is not a new phenomenon in Turkish politics as it has been in effect for at least a decade. What we see in the case of Turkey is that in terms of state-citizen relations, the form and aesthetic of secrecy triumph over the content of secrets. The decisive factor becomes the position people take vis-à-vis the secret, with which side they associate with, and whose secret they take as their own.

\section{References}

Associated Press. 2014. Turkish PM says incriminating tapes are fake amid growing phone-tapping scandal. The Telegraph, February 25. http://www.telegraph.co.uk/news/worldnews/europe/turkey/10659567/Turk ey-PM-says-incriminating-tapes-are-fake-amid-growing-phone-tappingscandal.html

Arendt, Hannah. 1968. The origins of totalitarianism. New York: Harcourt, Brace \& World. 
Aydınlı, Ersel. 2011. Ergenekon, new pacts, and the decline of the Turkish "inner state." Turkish Studies 12, no. 2: 227-239.

Balcı, Ali. 2010. A trajectory of competing narratives: The Turkish media debate Ergenekon. Mediterranean Quarterly 21, no. 1: 76-100.

Bratich, Jack Z. 2008. Conspiracy panics: Political rationality and popular culture. Albany: State University of New York Press.

Esen, Berk, and Sebnem Gumuscu. 2016. Rising competitive authoritarianism in Turkey. Third World Quarterly 37, no. 9: 1581-1606.

Fenster, Mark. 2008. Conspiracy theories: Secrecy and power in American culture. Minneapolis: University of Minnesota Press.

Freud, Sigmund. 1997. On the mechanism of paranoia. In General psychological theory: Papers on metapsychology, by Philip Rieff, 29-48. New York: Touchstone.

Galli, Carlos. 2012. Hamlet: Representation and the concrete. In Political theology and early modernity, by Graham Hammill and Julia Reinhard, 6083. Chicago: The University of Chicago Press.

Gray, Matthew. 2010. Conspiracy theories in the Arab world: Sources and politics. London: Routledge.

Hobbes, Thomas. 1998. Leviathan. Oxford: Oxford University Press.

Huizinga, Johan. 1949. Homo ludens: A study of the play-element in culture. London: Routledge \& Kegan Paul.

Insel, Ahmet. 2003. The AKP and normalizing democracy in Turkey. The South Atlantic Quarterly 102, no. 2/3: 293-308.

Jameson, Fredric. 1990. Cognitive mapping. In Marxism and the interpretation of culture, by Cary Nelson and Lawrence Grossberg, 347-360. London: Macmillan. 
Jenkins, Gareth. 2009. Between fact and fantasy: Turkey's Ergenekon investigation. Washington DC: Central Asia - Caucasus Institute Silk Road Studies Program.

Jenkins, Gareth. 2011. Ergenekon, Sledgehammer, and the politics of Turkish justice: Conspiracies and coincidences. Middle East Review of International Affairs 15, no. 2: 1-9.

Kahn, Victoria. 2004. Wayward contracts: The crisis of political obligation in England, 1640-1674. Princeton: Princeton University Press.

Kant, Immanuel. 2000. Critique of the power of judgment. Cambridge: Cambridge University Press.

Kristeva, Julia. 1982. Powers of horror: An essay on abjection. New York: Columbia University Press.

Kuru, Ahmet, and Alfred Stepan. 2012. Democracy, Islam, and secularism in Turkey. New York: Columbia University Press.

Letsch, Constance. 2014. Leaked tapes prompt calls for Turkish PM to resign. The Guardian, February 25. https://www.theguardian.com/world/2014/feb/25/leaked-tapes-callserdogan-resign-turkish-pm

Mardin, Şerif. 1973. Center-periphery relations: A key to Turkish politics? American Academy of Arts \& Sciences 102, no. 1: 169-190.

Navaro-Yashin, Yael. 2002. Faces of the state: Secularism and public life in Turkey. Princeton: Princeton University Press.

North Atlantic Treaty Organization. 2013. NATO glossary of abbreviations used in NATO documents and publications. AAP-15. http://www.dtic.mil/doctrine/doctrine/other/aap15.pdf

Schmitt, Carl. 2007. The concept of the political. Trans. George Schwab. Chicago: The University of Chicago Press. 
Strauss, Leo. 2007. Notes on Carl Schmitt, the concept of the political. In The concept of the political, by Carl Schmitt, Trans. J. Harvey Lomax, 99-121. Chicago: The University of Chicago Press.

Taş, Hakkı. 2014. Turkey's Ergenekon imbroglio and academia's apathy. Insight Turkey 16, no. 1: 163-179.

Tuğal, Cihan. 2009. Passive revolution: Absorbing the Islamic challenge to capitalism. Stanford, CA: Stanford University Press.

Wolin, Richard. 1992. Carl Schmitt: The conservative revolutionary habitus and the aesthetics of horror. Political Theory 20, no. 3: 424-447.

Zizek, Slavoj. 1995. The sublime object of ideology. London: Verso. 
1 After the latest constitutional change in April 2017, he returned to his party as both the head of the state and the party leader.

2 Cumhur Başkanını Seçiyor, YouTube video, posted by "Milletin Adamı," August 4, 2014, https://www.youtube.com/watch?v=tvj8XdL-A8M

3 The almost century-long history of modern Turkey is rich in terms of coup d'états. The first military coup ousted the Democrat Party (DP) government, which came to power when it defeated the Republican People's Party that had been the only legitimate party in the one-party regime of the early years of the republic. The following two coups took place in 1971 and 1980, the main target of which was the rising left-wing politics. In 1997, a partial military intervention - also known as the "postmodern coup" - forced the Islamist Welfare Party (RP) to resign from the coalition government. Finally, a statement was released on the military headquarters' [Genelkurmay] official website after the presidential candidacy declaration of then Deputy Prime Minister, Abdullah Gül. The apparent reason behind the army's statement was reported to be Gül's wife's wearing a headscarf, which went against the secularist identity of the Turkish state.

4 In the aftermath of the military intervention in 1997, the Welfare Party, qua the Islamist partner of the ruling coalition, was forced to withdraw from the government. This led to a schism within the party as Erdoğan and some other prominent names within the party, who were referred as "reformists," started to challenge the sway of the "traditionalist" that have been in control of the party from the very beginning. A couple of years later, the "reformist" faction parted ways with the traditionalist cadres and started a new party under the name, The Justice and Development Party's (AKP). Shortly after its foundation, the party had the seat majority in the parliament and formed a single-party government thanks to its electoral triumph in 2003 general elections. For some commentators, this was the beginning of a "civilianization" and "democratization" process in which the existing political establishment with authoritarian and absolutist elements at its center that had been established by the military junta in the early 1980 s was gradually weakened and replaced by another coalition.

5 Ergenekon is originally the name of a founding myth with Turkic and Mongolian origins. The Turkic version is a myth of defeat, rebirth, and the beginning of a golden age in that order. According to the myth, ancient Turks seek refuge in a legendary valley called Ergenekon after a devastating military defeat. After being trapped there for centuries, a blacksmith melted the rock and opened a pathway to the outside world. Once they were out, they formed the Turkic Khaganate. In that respect, the term Ergenekon insinuates ideological ties with Turkism, which originated as a pan-nationalism in the late 19th century along with and to some degree as a response to earlier related movements such as pan-Slavism and pan-Germanism and currently represented mainly by the ultra-nationalist party Nationalist Movement Party (MHP).

6 To actualize its objectives, the AKP government formed an alliance with another Islamist group with an agenda separate from the Islamist government, Fethullah Gülen and his followers, whose influence was swiftly growing in various state institutions including the army they have been "infiltrating" for decades. Ultimately, this coalition triumphed in their struggle against the old establishment but the process of civilianisation of politics was not without its pitfalls: In their article, Esen and Gumuscu $(2016,1585)$ write as follows: "[...] the process of civilianisation of politics came at a high cost, as the AKP's undemocratic and illiberal measures in highly politicised trials against the members of the armed forces eroded rule of law as well as fundamental human rights. For instance, defendants of both the 'Ergenekon' and 'Sledgehammer' cases witnessed a violation of their fundamental rights in due process. As the recent conflict between the AKP government and the Gülen movement had been revealed, the party apparently utilized courts under the influence of the Gülenists to subdue and intimidate the rank and file in the armed forces, often through fabricated evidence and violation of due process." 
7 What Jenkins refers to as "the politics of absurd" partially derives from the tendency to aestheticize the Ergenekon affair along with global conspiracist imaginations.

8 Herein, Ergenekon trial can be seen as one ring of the chain public revelations that started with the erstwhile Italian prime minister, Giulio Andreotti admitted the existence of Gladio within the Italian state in officially 1990.

9 "Ergenekon için kim ne demişti?" Sözcü, 21 April, 2016.

10 "Erdoğan: Türkiye'nin Önündeki Engel Bürokrasi," Hürriyet, 28 November, 2004. "Bürokrasi ve yargı en büyük engel," Akşam, 18 December, 2012. "Ak Parti'de 'Engelsiz Türkiye için Evet' programı," Star, 21 March, 2017.

11 The Gülenist newspapers in particular contained "eccentric" and conspiratorial explanations of the Ergenekon case. One can speculate that the Gülenists' worldwide network and significant presence in civil societies of Western countries allowed them to provide global conspiracy narratives and incorporate the existing conspiracist aesthetics in Western popular culture and non-mainstream public forums. Following the power struggle between the government and the Gülen movement, the media outlets under the latter's control as well as their Internet archives were closed down. After the coup attempts in July 2016, their previous issues were put under lock and key in state archives, which made it extremely hard to access the pertinent content.

12 "Genelkurmay Başkanlığı: sekiz askeri personele gözaltı," Milliyet, 26 December, 2009. "Kozmik oda dün de arandı/ TSK: Tamamen yasal çerçevede," Radikal, 30 December, 2009. "Kozmik odada en uzun gün," Zaman, 28 December, 2009. "Genelkurmay'da 'kozmik oda' zirvesi," Zaman, 8 January, 2010.

13 "Türkiye'nin 'karakutu'su aralanıyor." Zaman, 29 December, 2009.

14 "Arka planda görünmeyen Türkiye var, kolu nereye uzanıyor bilemiyoruz," Zaman, 25 December, 2009.

15 Here one should also mention that the elevation of this seemingly national event to the "dignity" of international politics has a particular significance on the axis of East-West relations and within the postcolonial mindset continues to loom large in Turkey.

16 The seriousness of Schmitt's theory can be observed most explicitly in the Ernst of Ernstfall, which is usually translated into English as "state of emergency" or "state of exception." However, the fact that Ernst means "seriousness" suggests that the term can also be translated as "state of seriousness" or "serious situation."

17 Büyük Oyun! Gezi olaylarının gerçek yüzünü gör Türkiyem!, YouTube video, posted by "AKGenclikGM," June 25, 2013, https://www.youtube.com/watch?v=D0zHnTC6n-Q 